\title{
Cash Management in Hospitality Sector of Western Europe
}

\author{
Wisal Ahmad ${ }^{1}$, Shahwali Khan ${ }^{2}$, Mohammad Sohail Yunis ${ }^{3}$
}

\begin{abstract}
The study investigates the effect of factors explaining the cash holdings of hospitality sector in five countries of Western Europe, namely, France, Germany, Spain, Italy and United Kingdom for a period of 12 years (2005-2016). The effect of parameters i.e., size, leverage, capital expenditures, growth opportunities, liquidity, cash flow, asset intangibility, cash flow volatility, dividend payments and stock exchange on cash holdings has been empirically tested by employing dynamic estimation methodology i.e., Generalized Method of Moments (GMM). The findings reveal that growth opportunities and dividend payments have a positive effect on cash holdings, while size, leverage, liquidity, cash flow, asset intangibility, cash flow volatility and stock exchange pose a negative effect. Moreover, the subsectors such as airlines, gambling and restaurants and bars are holding more cash in comparison to the travel and tourism. The study empirically supports the trade-off, pecking order and free cash flow theories of cash holdings for the hospitality sector. The academic implications of the study reflect that larger companies in the hospitality sector of Western Europe are more diversified and hence amass more cash. Similarly, supporting the cash flow theory, larger hospitality sector companies hold more cash to bar the agency issues. Moreover, companies in the hospitality sector keep less cash as such companies face close monitoring and attain leverage cheaply. Supporting the trade off theory, companies in the hospitality sector hold considerable fund of cash to counter cash shortages for making investments. Furthermore, companies in the hospitality sector experiencing more cash flows keep less cash, as influx of cash flows serve as a source of liquidity. Furthermore, to be able to pay stable dividends, the hospitality sector companies amass more cash and hence support the trade off theory. The practical implications of the study shows that by utilizing the empirical findings in this study, an investor sensitive to empire-building traits of managers for their private benefits, can infer that large hospitality companies with more leverage and capital expenditures will hold less cash. However, holding excessive cash in such companies can create
\end{abstract}

1 Assistant Professor, Abdul Wali Khan University, Mardan, KP, Pakistan.

Email:wisalahmad@awkum.edu.pk.

2 Assistant Professor, Institute of Management Sciences, Peshawar, KP, Pakistan.

Email: shah.wali@imsciences.edu.pk .

3 Assistant Professor, Institute of Management Sciences, Peshawar, KP, Pakistan.

Email: sohail.younis@imsciences.edu.pk.

\section{ARTICLE HISTORY}

24 Aug, 2019 Submission Received

29 Oct, 2019 First Review

24 Jan, 2020 Second Review

29 May, 2020 Third Review

10 Jun, 2020 Accepted 
agency problems. On the other hand, large hospitality companies holding more cash would have an ease in practicing debt financing as holding more cash is an indication of diversification and expansion, making shareholders more heedful about their net earnings.

Keywords: Cash holdings, hospitality, Western Europe.

JEL Classification: Z31; L8; G3

\section{Introduction}

This study examines the hospitality sector as a whole for specific multiple countries of Western Europe to observe the impact of various determinants on cash holdings. Considering the hospitality sector and its subsectors as a whole, Ahmad and Adaoglu (2019) explore the determinants of cash holdings of companies in the United Kingdom (UK) only. This study adds to the cash holding literature by examining an "asset-intensive", "labor-intensive" and "growth-prioritizing" sector (Kim, Woods, \& Kim, 2011, p. 569). Similarly, in the European Union (EU), tourism sector is ranked third in terms of generating economic activity due to remarkable worldwide arrivals (Bahreini \& Adaoglu, 2018). According to World Tourism Organization (2018), the five EU countries, i.e., France, Spain, Italy, Germany and the UK, are not only ranked among the top ten tourists destinations in terms of worldwide arrivals, but are also the top five EU countries in terms of financial contribution to the respective economies. Following the influx of international arrivals in these countries, the total monetary contribution made by France ( $\$ 60.7$ billions), Spain ( $\$ 68$ billions), Italy ( $\$ 44.2$ billions), Germany (39.8 billions) and UK ( $\$ 51.2$ billions) is $\$ 263.9$ billions (World Tourism Organization, 2018), which provides reason for analyzing determinants of cash holdings in these five countries of Western Europe. The study analyses the cash management of hospitality sector companies to respond to the question on how various determinants in these companies react to the bulk of cash generated in respect of worldwide arrivals, thereby, making the study unique. Moreover, the airlines (ALINES), gambling (GAMB), hotels (HOTL), recreational services (REC SER), restaurants and bars (RES \& BARS), and travel and tourism (TRA \& TRM) are the six subsectors investigated to find out the magnitude of holding cash by these subsectors, adding more uniqueness to the study.

According to the extant literature, the three major theories i.e., trade-off, pecking order and free cash flow explain cash holding behaviours of companies. The trade-off theory (precautionary motive) states that to overcome financial distress, companies prefer to hold more cash (Tahir, Alifiah, Arshad, \& Saleem, 2016; Opler, Pinkowitz, Stulz, \& Williamson, 1999), whereas the transaction approach helps companies to obtain external funds with lower transaction costs in the presence of information that 
are asymmetric (Lee \& Shin, 2018; Ferreira \& Vilela, 2004; Myers \& Majluf, 1984). According to Jensen \& Meckling, (1976), the transaction cost of availing the external funds would be high if companies are facing elevated agency costs of debt. Thus, such companies facing liquidity problems need to amass cash to curtail the higher transaction cost of grabbing external finances. The pecking order theory states that companies in situations of financial distress need to utilize internal funds as primary source and the external finances as the secondary source of financing (Sultanov, 2018; Myers \& Majluf, 1984). The free cash flow theory postulates that managers amass cash to pursue empire-building interests, which reduce value of the companies (Iacopetta, Minetti, \& Peretto, 2019; Jensen, 1986).

This study contributes to the cash management literature as all the three theories i.e., trade-off, pecking order and cash flow are empirically tested and various determinants of cash holdings are explained for the hospitality sector in Western Europe. Within the framework of these three theoretical models, this study explores these determinants in hospitality sector and six of its sub-sectors. This study employs STATA econometrics software to estimate the dynamic modeling methodology i.e., Generalized Method of Moments (GMM), to investigate the effect of explanatory variables on cash holdings. Panel data set winsorized at $1 \%$ level is extracted from 80 companies of Western Europe between 2005-2016, with a total of 676 observations. Results show that dividend-paying companies and those having high growth opportunities hold more cash. While larger companies with more leverage, liquidity, cash flows, intangible assets, cash flow volatility and those listed on London Stock Exchange tend to keep less cash. The study also confirms that airlines, gambling and restaurants and bars hold more cash as compared to the sub-sector of travel and tourism.

The remaining paper is organized as follows. Section 2 presents the literature review and hypotheses development while section 3 describes the methodology. Empirical results and discussions are presented in Section 4. The last section is conclusion and includes the implications and the suggestions for future studies.

\section{Literature Review and Hypotheses Development:}

The hospitality sector is governed by basic unique attributes of high leverage, capital intensity, risk and high competition that help in examining corporate theories and its practices (Ahmad \& Adaoglu, 2019). Relative to other sectors, the hospitality sector is not only more capital-intensive and competitive, but also bear more risk and leverage (Singal, 2015). In the light of these basic unique attributes, the study done by (Ahmad \& Adaoglu, 2019) show that cash holdings of UK's hospitality sector is positively influenced by growth opportunities, profitability and risk and negatively affected by leverage, liquidity, intangible assets and payments of dividends. In the 
literature, there are very few empirical studies which take into account these unique attributes. For instance, Kim, Woods, and Kim (2011) investigate the determinants of cash holdings for restaurant sector in the United States (US). Similarly, Kim and $\mathrm{Gu}$ (2009) state that "Hospitality firms are fixed assets-intensive and investment opportunities would require large amounts of new capital” (p. 364). Kim, Woods, and Kim (2013) analyze the financial characteristics of cash-rich and cash-poor restaurant corporations in the US. Mung and Jang (2015) examine working capital, cash holdings and profitability of the restaurant corporations in the US. Furthermore, Dogru and Sirakaya-Turk (2017) investigate the value of cash holdings in hotel corporations in the US. Uyar and Kuzey (2014) examine the cash management issues in the emerging economy of Turkey. The current study aims to investigate the effect of determinants on holding cash in the light of these unique attributes by taking into account all the sub sectors of hospitality sector of Western Europe.

\section{Explanatory Variables}

Prior literature shows that the size of the firm is an important determinant of cash holdings. For instance, large corporations raise cheaper funds as compared to smaller ones (Fichtner, Heemskerk, \& Garcia-Bernardo, 2017; Peterson \& Rajan, 2002). Supporting the trade-off theory, Pastor \& Gama (2013) establish a negative association between size and cash holdings. Large corporations are more diversified, have less financial distress costs, and enjoy the benefits of economic scale in both operations and financing (Butler, 2016; Al-Najjar \& Belghitar, 2011). However, pecking order theory suggests companies larger in size require to pile up cash for making investments (Sultanov, 2018; Ferreira \& Vilela, 2004). Furthermore, the free cash flow theory argues that such firms amass more cash to overcome the problems related to agency conflicts (Yung \& Chen; 2018; Ferreira \& Vilela, 2004). Therefore, similar implications are expected for companies of Western Europe hospitality sector. Capitalizing on the above arguments from the literature, the following hypothesis is derived.

Hypothesis 1: There is a negative relation of cash holdings with size

Companies use financial leverage as a viable alternative for liquid assets (Maheshwari \& Rao, 2017). Particularly, companies having better reach to debt markets tend to hold less cash (Al-Najjar \& Belghitar, 2011; D’Mello, Krishnaswami, \& Larkin, 2008). Furthermore, leveraged companies keep less cash due to being monitored closely by lenders (Cui, John, Pang, \& Wu, 2018; Ferreira \& Vilela, 2004). On the other hand, highly levered corporations keep more cash under their control to overcome the increased risk of default and bankruptcy. Therefore, following the expectations of trade-off theory, the association between leverage and cash holdings is positive or negative. Similarly, according to the prediction of pecking order theory, a negative 
association between leverage and cash holding exists as according to Ferreira \& Vilela, (2004) the cash holdings start to reduce due to rise in debt when the investments exceeds the retained earnings. The hospitality sector is characterized by high fixed costs, asset intensiveness, and high financing needs. These characteristics make the leverage effect on cash holdings significant for the hospitality sector. In the hospitality sector, leverage is expected to be an alternative source for cash, thus, leading to the following hypothesis.

Hypothesis 2: There is a negative relation of cash holdings with leverage

Capital expenditures help companies to achieve high profitability and hence keep less cash (Maheshwari \& Rao, 2017). Bates, Kahle, and Stulz (2009) posit that capital expenditures enable companies to acquire tangible assets to be used as collateral for borrowing and hold low cash. Similarly, Kim et al. (2011) and Uyar and Kuzey (2014) find that there exists a negative relation of capital expenditures with cash holdings. On the other hand, Riddick and Whited (2009) argue that companies with more capital expenditures need to hold more cash to counter the threat of financial distress and supports trade off theory. In addition, for capital and asset intensive hospitality sector, the effect of capital expenditures on cash holdings is expected to be strong. Therefore, on the basis of the above discussion, the following hypothesis is proposed.

Hypothesis 3: There is a negative relation of cash holdings with capital expenditures

Companies amass cash to save on opportunity costs in tapping new projects and support the trade-off theory (Uyar \& Kuzey, 2014). Similarly, the pecking order theory proposes that there exists a positive relation and companies keep more cash to avoid the adverse selection costs of external financing for projects. Furthermore, the impact of growth opportunities on cash holdings is expected to be strong in the cyclical, asset and capital expenditures intensive, and growth prioritizing hospitality sector. Hence, the following hypothesis is presented.

Hypothesis 4: There is a positive relation of cash holdings with growth opportunities

Apart from cash, liquid assets are termed as an alternative source of cash (Mulvey, \& Holen, 2016; Al-Najjar \& Belghitar, 2011). Hence, companies amass less cash with more liquidity (Uyar \& Kuzey, 2014) and support the trade-off theory. Moreover, substitutes of liquid assets are a cheap and easy source of cash during cash shortages (Ferreira \& Vilela, 2004; Ozkan \& Ozkan, 2004). Similarly, the liquidity effect holds for the cyclical, asset intensive and growth prioritizing hospitality sector. Based on the above, we propose the following hypothesis. 
Hypothesis 5: There is a negative relation of cash holdings with liquidity

Jensen (1986) argues managers amass excessive cash to achieve autonomy in managerial decisions for their private benefits. Moreover, managers face intense pressure from borrowers to finance new projects. Therefore, high cash flow from operations helps managers to fund these projects, lowering need for holding cash and supports the trade-off theory.

On the other hand, supporting the pecking order theory, companies with higher cash flows stockpile cash (Hansen, \& Wagner 2017; Drobetz \& Grüninger, 2007) to overcome the contingent events (Opler et al., 1999) and possess the ability to save more (Lian, Sepehri, \& Foley, 2011). A strong impact of cash flow on cash holdings is expected in the hospitality sector, particularly due to the capital-, asset- and growthintensive characteristics. The hospitality sector faces financial constraints due to such characteristics. Hence, the following hypothesis is proposed.

Hypothesis 6: There is a negative relation of cash holdings with cash flow

There is a positive relation of cash holdings with asset intangibility and also supports the trade-off theory (Antonio, Kadyrzhanova, Jae, \& Sim, 2013). The intangible assets can reduce the borrowing capacity of companies since they possess high information asymmetry, contingent liquidation value and less collateral value (e.g., Williamson, 1988; Shleifer \& Vishny, 1992). This can lead to operational and financial inflexibility and these companies amass more cash.

On the other hand, Martinez-Sola, Garcia-Teruel, and Martinez-Solano (2011) find a negative relation of cash holdings with asset intangibility. The relationship can also be negative due to the remarkable advances in information and communication technologies. Peculiarly, in the recent times, companies have gradually started investing more in intangibles assets to not only increase their uniqueness but also to improve their competitive advantage (Lev, 2000). Furthermore, internet gambling has started to pop up as countries are getting more advanced in technology and is growing quite swiftly (Griffiths \& Parke, 2002). Therefore, gambling companies are more dependent on intangible assets and have become more technology-, service- and internet-oriented. Hence, companies operating in hospitality sector can gain competitive advantage to become more profitable due to the effective use of information technologies and amass less cash. Thus, the following hypothesis is presented.

Hypothesis 7: There is a negative relation of cash holdings with asset intangibility

Cash becomes significant in times of hard business settings to absorb detrimental shocks and to survive in situations of uncertainty. Companies facing more variabil- 
ity in cash flows are highly exposed to cash shortages (Nafees, Ahmad, \& Rasheed, 2017; Ozkan \& Ozkan, 2004) and hence need to amass cash, which supports the precautionary motive of trade-off theory. Financially constrained companies with more variability in cash flows create uncertainty about future cash holdings (Han \& Qiu, 2007). Variability in cash flows subject companies to lose lucrative investment opportunities (Minton and Shrand, 1990). On the other hand, Paskelian, Bell, and Nguyen (2010) find a negative relation of cash holdings with cash flow variability. Companies which are characterized by high cost of capital cannot hold cash as the holding cost is higher as compared to the cash flows generated (Ferreira \& Vilela, 2004). Hence, the following hypothesis is presented.

Hypothesis 8: There is a negative relation of cash holdings with cash flow volatility

Companies that pay stable dividends are holding less cash and can obtain cheaper funds when required (Al-Najjar \& Belghitar, 2011). On the other hand, companies amass cash as a precautionary motive (trade-off theory) to pursue the dividend stability policy (Maheshwari and Rao, 2017). Financially constrained companies find it onerous to raise further debt. By reducing their dividends, such companies may uplift their retained earnings to provide for cash requirements. In the cyclical, asset intensive, growth prioritizing and high capital expenditures ectors such as hospitality sector, it is expected that companies may face financial constraints in the hospitality sector.

Hypothesis 9: There is a positive relation of cash holdings with dividend payments

In London Stock Exchange (LSE) of the UK, well-established and larger companies of hospitality sector are traded, and such companies have easier access to domestic and international funds coupled with a knowledgeable investor base and a poised regulatory atmosphere (Ahmad \& Adaoglu, 2019). However, in the main stock exchanges of France, Spain, Italy and Germany, relative to LSE, small and medium size companies of hospitality sector are traded. Based on the fundamental characteristics of high risk, high competitiveness, asset- and labor-intensiveness and growth-prioritization, the hospitality sector companies that are traded in the LSE are deemed to hold more cash, as according to Hardin, Highfield, Hill, and Kelly, (2009), cash is needed to fund lucrative investment projects, supporting the trade off theory. On the other hand, companies listed on LSE are normally larger in size, followed by easier access to domestic and international financial markets to generate funds and amass less cash. To capture this relationship, a stock exchange dummy variable is used and the following hypothesis is proposed.

Hypothesis 10: There is a negative relation of cash holdings with the stock exchange 


\section{Explained Variable}

The cash holdings (dependent variable) (CSH) include cash and cash equivalents containing cash on hand, short-term investments, petty cash, checks received but not yet deposited, and saving accounts. This study defines cash holdings as the ratio of cash and cash equivalents to total assets (e.g., Drobetz \& Grüninger, 2007; Lian et al., 2011). As the ratio increases, the cash holdings of the companies also increases and vice verse.

In Table 1, the determinants of cash holdings, their abbreviations, the expected relationship and Predicted signs by theories are summarized. ${ }^{4}$

\section{Methodology}

\subsection{Data, Sample and Descriptive Statistics}

As the Industry Classification Benchmark (ICB) is adopted by Thomson Reuters Datastream and WorldScope in 2005, therefore data are collected from these databases starting from 2005 till 2016. Apart from this, the chosen time line is cov-

Table 1: Definitions of Determinants, the Hypothesized Relationship and Predicted signs by theories

\begin{tabular}{|c|c|c|c|c|}
\hline $\begin{array}{c}\text { Determinants } \\
\text { as Explanatory } \\
\text { variables }\end{array}$ & $\begin{array}{c}\text { Hypothesized } \\
\text { signs }\end{array}$ & $\begin{array}{c}\text { Predicted signs by } \\
\text { trade off theory }\end{array}$ & $\begin{array}{c}\text { Predicted signs } \\
\text { by pecking order } \\
\text { theory }\end{array}$ & $\begin{array}{c}\text { Predicted signs by } \\
\text { cash flow theory }\end{array}$ \\
\hline Size (SIZ) & Negative & Negative & Positive & Positive \\
\hline Leverage (LVR) & Negative & Negative/Positive & Negative & Negative \\
\hline $\begin{array}{c}\text { Capital Expendi- } \\
\text { tures (CEX) }\end{array}$ & Negative & Negative & Not Applicable & Not Applicable \\
\hline $\begin{array}{c}\text { Growth Opportu- } \\
\text { nities (GOP) }\end{array}$ & Positive & Positive & Positive & Negative \\
\hline Liquidity (LQY) & Negative & Negative & Not Applicable & Not Applicable \\
\hline Cash Flows (CFL) & Negative & Negative & Positive & Not Applicable \\
\hline $\begin{array}{c}\text { Asset Intangibility } \\
\text { (AIT) }\end{array}$ & Negative & Positive & Not Applicable & Not Applicable \\
\hline $\begin{array}{c}\text { Cash Flow Volatil- } \\
\text { ity (CFV) }\end{array}$ & Negative & Positive & Not Applicable & Not Applicable \\
\hline $\begin{array}{c}\text { Dividend Pay- } \\
\text { ments (DVD) }\end{array}$ & Positive & Positive & Not Applicable & Not Applicable \\
\hline $\begin{array}{c}\text { Stock Exchange } \\
\text { (STX) }\end{array}$ & Negative & Positive & Not Applicable & Not Applicable \\
\hline
\end{tabular}

4 The definitions of all the determinants are given at the end of Table 4. 
ering the era of global financial crisis i.e., 2008-2009, which is serving the purpose of capturing the time specific effects in these years for the hospitality sector of the target countries. Applying a winsorization level of $1 \%$, panel data are collected for 80 hospitality sector companies. The descriptive statistics are shown in Table 2, where leverage and liquidity values indicate that the hospitality sector for Western Europe is debt-intensive and faces liquidity constraints. The hospitality sector is governed by basic unique attributes of high leverage, capital intensity, risk and high competition that help in examining corporate theories and its practices (Ahmad \& Adaoglu, 2019). The hospitality sector is not only more capital-intensive and competitive, but also bear more risk and leverage relative to other sectors, (Singal, 2015; Ahmad \& Adaoglu, 2019), thus making this sector different from the other ones.

Table 3 provides Pearson correlation matrix among the variables. The correlation between any two regressors is less than 0.50 . Thus, multicollinearity is not likely to be a problem in the estimations. The table shows that CEX, GOP, LQY, CFL and CFV are positively correlated with $\mathrm{CSH}$ and the correlations are statistically significant. CSH is negatively correlated with SIZ and LVR, and the correlations are statistically significant. Based on univariate analysis, the correlations signs for SIZ, LVR, GOP and AIT are in line with the hypothesized relationships in Table 1, but this is not

Table 2: Descriptive Statistics

\begin{tabular}{|c|c|c|c|c|c|}
\hline & Mean & Median & SD & Min & Max \\
\hline CSH & 0.1444 & 0.0712 & 0.1616 & 0.0012 & 0.7639 \\
\hline SIZ & 13.2258 & 13.3353 & 2.1447 & 8.4976 & 17.1494 \\
\hline LVR & 0.6163 & 0.5888 & 0.2363 & 0.0870 & 1.3929 \\
\hline CEX & 0.0609 & 0.0402 & 0.0630 & 0.0006 & 0.3471 \\
\hline GOP & 2.7745 & 1.8350 & 4.4202 & -5.7800 & 29.8600 \\
\hline LQY & -0.1127 & -0.1166 & 0.1663 & -0.5979 & 0.5817 \\
\hline CFL & 0.0736 & 0.0804 & 0.1085 & -0.3448 & 0.4069 \\
\hline AIT & 0.2031 & 0.0963 & 0.2250 & 0.0000 & 0.8715 \\
\hline CFV & 0.0574 & 0.0297 & 0.0799 & 0.0022 & 0.4517 \\
\hline DVD & 0.6095 & 1.0000 & 0.4882 & 0.0000 & 1.0000 \\
\hline STX & 0.2264 & 1.0000 & 0.4188 & 0.0000 & 1.0000 \\
\hline
\end{tabular}


the case for CE, LQY, CFL and CFV. Further multivariate analysis is needed and is carried out in the following sections.

\subsection{Econometric model}

The dynamic panel data estimator i.e., system generalized method of moments (GMM) developed by (Arellano \& Bover, 1995) is employed in the study to achieve the research objectives in the best possible way, the reasons of which are explained in detail. This methodology has been used in several empirical studies, for instance,

Table 3: Pearson Correlation Matrix

\begin{tabular}{|c|c|c|c|c|c|c|c|c|c|}
\hline & CSH & SIZ & LVR & CEX & GOP & LQY & CFL & AIT & CFV \\
\hline CSH & 1 & & & & & & & & \\
\hline SIZ & $-0.266^{*}$ & 1 & & & & & & & \\
\hline LVR & $-0.200^{*}$ & $0.405^{*}$ & 1 & & & & & & \\
\hline CEX & $0.069^{* * *}$ & $-0.123^{*}$ & $-0.089^{* *}$ & 1 & & & & & \\
\hline GOP & $0.073^{* *}$ & -0.048 & $0.013^{*}$ & -0.011 & 1 & & & & \\
\hline LQY & $0.069^{* *}$ & $-0.149^{*}$ & $-0.497^{*}$ & -0.047 & -0.034 & 1 & & & \\
\hline CFL & $0.112^{*}$ & $0.120^{*}$ & $-0.285^{*}$ & 0.003 & $0.121^{*}$ & $0.108^{*}$ & 1 & & \\
\hline AIT & $-0.162^{*}$ & $0.188^{*}$ & $0.083^{*}$ & $-0.252^{*}$ & $-0.063^{* * *}$ & $-0.181^{*}$ & $0.080^{*}$ & 1 & \\
\hline CFV & $0.213^{*}$ & $-0.368^{*}$ & $0.075^{* *}$ & -0.029 & 0.025 & $-0.205^{*}$ & $-0.379^{*}$ & -0.019 & 1 \\
\hline
\end{tabular}

Notes: $10 \%, 5 \%$ and $1 \%$ statistical significance is shown by ${ }^{* *},{ }^{* *}$ and ${ }^{*}$ respectively.

Ozkan \& Ozkan (2004), Al-Najjar \& Belghitar (2011) and Uyar \& Kuzey (2014). This methodology helps to counter the problem of endogeneity, which in our study is detected by Durbin-Wu Hausman test $\left[F=4.0 e^{+} 17\right.$ (p-value: 0.000 )], i.e., the regressors are correlated with the error term. The main causes of endogeneity include omitted variables, simultaneity and measurement errors. GMM overcomes the endogeneity problem by plugging the instruments. The features of the instruments are that these are explanatory variables added to the model, having correlation with the other explanatory variables, but are uncorrelated with the error term. The methodology employed also deals with various other econometric problems, for instance, heteroskedasticity, autocorrelation and fixed effects. According to Baum, Schaffer \& Stillman (2002), the GMM deals with heteroskedasticity by making use of the orthogonality conditions to allow for efficient estimation in the presence of heteroskedasticity of unknown form. The GMM also helps to counter the problem of autocorrelation by obtaining efficient estimatiors (Wooldridge, 2001), which also eliminates the unobserved, time-invariant individual specific effects (fixed effects) and comes up with consistent estimation results (Ozkan, 2007). 
The dynamic model is given below

$$
\begin{aligned}
& \mathrm{CSH}_{i, t}=\alpha+\delta_{0} \mathrm{CSH}_{i, t-1}+\delta_{1} S I Z_{i, t}+\delta_{2} \mathrm{LVR}_{i, t}+\delta_{3} C E X_{i, t}+\delta_{4} G O P_{i, t}+\delta_{5} L Q Y_{i, t}+{ }_{5} \\
& \delta_{6} C F L_{i, t}+\delta_{7} A I T_{i, t}+\delta_{8} C F V+\delta_{9} D V D_{i, t}+\delta_{10} S T X_{i, t}+\gamma_{i}+\mu_{t}+\varepsilon_{i, t}
\end{aligned}
$$

Whereas $\delta_{0}$ is the difference of 1 and the adjustment coefficient $\left(1-\delta_{0}\right)$, refer to as the adjustment costs. Similarly, $\gamma_{i}$ and $\mu_{t}$ denote the industry and the time dummy factors to grab subsector and time specific effects. Moreover $\varepsilon_{\mathrm{i}, \mathrm{t}}$ denotes the error term to grab unobserved shock.

\subsection{Empirical Results and Discussion of Findings}

The empirical results are shown in Table 4. Considering the three underlying theories and the unique attributes of travel and leisure sector, the expected signs are hypothesized. Table 4 shows that the lagged dependent variable i.e., $\mathrm{CSH}_{\mathrm{t}-1}$ carries a coefficient value of 0.55 and is positive, which is in line with the findings of Ozkan \& Ozkan (2004) and Uyar \& Kuzey (2014). The positive sign confirms the dynamic nature of the model used. The result helps to support the argument of Ozkan and Ozkan (2004), i.e., companies need to adjust to target cash levels. Moreover, as shown in Table 4, the adjustment coefficient (1- $\left.\delta_{0}\right)$ in this study is 0.45 , which is comparatively lower than the similar values found by Ozkan \& Ozkan (2004) for British companies i.e., 0.6025 and Uyar \& Kuzey (2014) for Turkish companies i.e., 0.77. This shows that hospitality sector's companies in Western Europe adjust to the target cash relatively slowly than the British and Turkish companies due to less information asymmetries and less agency costs.

Furthermore, the coefficient of size (SIZ) shows a negative effect on cash holdings $(\mathrm{CSH})$ of hospitality sector. Large corporations raise cheaper funds as compared to smaller ones (Fichtner et al., 2017; Peterson \& Rajan, 2002) and tend to hold less cash, which shows that the companies in the hospitality sector are large in size. Supporting the trade-off theory, Pastor \& Gama (2013) establish a negative association between size and cash holdings. Large corporations are more diversified, have less financial distress costs, and enjoy the benefits of economic scale in both operations and financing (Butler, 2016; Al-Najjar \& Belghitar, 2011).

The negative relationship of leverage (LVR) with cash holdings reflects that the highly levered hospitality sector amass less cash as according to Ferreira and Vilela (2004), such companies face intense monitoring from lenders. Moreover, companies having better reach to debt markets tend to hold less cash (Al-Najjar \& Belghitar, 2011; D'Mello et al., 2008). The positive sign of growth opportunities (GOP) supports the trade-off and pecking order theories and shows that growth prioritizing and

5 The explanation regarding the abbreviations is given in Table 1. 
competitive hospitality sector keeps more cash. Companies intend to keep more cash to fund new projects (Uyar \& Kuzey, 2014) and to overcome the liquidity shortages (Hardin et al., 2009).

The negative sign of liquidity (LQY) supports the trade off theory and is consistent with the findings of Ahmad and Adaoglu (2019). Moreover, liquid assets are termed as an alternative source of cash (Mulvey, \& Holen, 2016; Al-Najjar \& Belghitar, 2011) and hence, companies amass less cash with more liquidity (Uyar \& Kuzey, 2014). Similarly, the cash flows (CFL) also pose a negative impact on cash holdings and support the trade off theory. Jensen (1986) argues that borrowers push managers to fund profitable projects. Hence the influx of cash flows emanating from operations supports these managers to finance projects and reduce the cash holding need.

Furthermore, following the high capital intensity of hospitality sector, the CSH is positively affected by asset intangibility (AIT) and supports the argument that companies are investing more in intangibles assets to improve their competitive advantage (Nakamura, 2001). Therefore, hospitality sector companies have become more technology-, service- and internet-oriented and can achieve high profitability after gaining competitive advantage due to the adequate use of information technologies and amass less cash.

For the riskier hospitality sector, the negative sign of cash flow volatility (CFV) shows support for the arguments of Ferreira and Vilela (2004), i.e., companies facing cash flow volatility incur elevated cost of capital and hold less cash.

The positive relationship of dividend dummy (DVD) with cash holdings helps to support the trade off theory (precautionary motive). Companies amass more cash to be able to pay stable dividends (Ozkan \& Ozkan, 2004). The negative sign of stock exchange dummy (STX) shows that hospitality sector companies keep less cash which are listed on London Stock Exchange (LSE) than the main stock exchanges of France, Spain, Italy and Germany. The finding supports the argument that the listed companies of LSE are bigger in size, which helps in obtaining finances easily and amass less cash (Ahmad \& Adaoglu, 2019).

In Table 4, the reference subsector of the study includes the travel and tourism subsector. The positive coefficients of the airlines (ALINES), gambling (GAMB) and restaurants and bars (RES \& BARS) show that companies in these subsector keep more cash. These findings related to the subsectors carry enormous economic significance. For instance, airlines sector is highly sensitive to fluctuations in economic conditions (Bodie, Kane, \& Marcus, 2011) and face high fluctuations in oil prices with more fixed costs (Keynes, 2009) and therefore need to hold more cash. Moreover, airlines 
Table 4: Estimation Results (GMM)

\begin{tabular}{|c|c|c|c|}
\hline Regressors & Expected sign & Coefficient & p-value \\
\hline $\mathrm{CSH}-1$ & + & $0.5685^{*}$ & 0.000 \\
\hline SIZ & - & $-0.0074^{*}$ & 0.006 \\
\hline LVR & - & $-0.0827^{*}$ & 0.000 \\
\hline CEX & - & -0.0395 & 0.153 \\
\hline GOP & . & $0.0021^{*}$ & 0.000 \\
\hline LQY & - & $-0.1739^{*}$ & 0.000 \\
\hline CFL & - & $-0.2010^{*}$ & 0.000 \\
\hline AIT & . & $-0.2264^{*}$ & 0.000 \\
\hline $\mathrm{CFV}$ & - & $-0.1832^{*}$ & 0.000 \\
\hline DVD & + & $0.0322^{*}$ & 0.000 \\
\hline STX & - & $-0.0403^{*}$ & 0.000 \\
\hline ALINES & . & $0.1096^{*}$ & 0.000 \\
\hline GAMB & . & $0.2064^{*}$ & 0.000 \\
\hline HOTL & . & 0.0058 & 0.670 \\
\hline REC SER & . & 0.0084 & 0.613 \\
\hline RES \& BARS & . & $0.0551^{*}$ & 0.006 \\
\hline Year dummies & . & Yes & - \\
\hline Constant & . & $0.5245^{* * *}$ & 0.099 \\
\hline Observations & . & 676 & - \\
\hline $\operatorname{AR}(1)$ & . & $-3.26^{*}$ & 0.001 \\
\hline $\operatorname{AR}(2)$ & . & 1.20 & 0.230 \\
\hline Hansen & & 50.35 & - \\
\hline
\end{tabular}

Notes: CSH is the cash and cash equivalent to total assets (TA); SIZ is the natural logarithm of TA; LVR is the Total Liabilities divided by TA; CEX is the Capital Expenditures divided by TA; GOP is the Market Value divided by Book Value; LQY is the difference of Net Working Capital and Cash divided by TA; CFL is the Operating Cash Flows divided by TA; AIT is the Intangible Assets divided by TA; CFV is the Standard Deviation of Cash Flows divided by TA; DVD carries value of 1 if dividend is paid and 0 otherwise. STX carries value of 1 if Company is listed on LSE and 0 otherwise. The null hypothesis of No Serial Correlation for First-and Second-order Autocorrelations is represented by Correlations 1 and 2. The null hypothesis of instrument validity is represented by Hansen test, distributed as chi-square. $10 \%, 5 \%$ and $1 \%$ statistical significance is shown by ${ }^{* * *},{ }^{* *}$ and ${ }^{*}$ respectively. 
larger in size need to financially compensate the chief executive officers (Gu \& Kim, 2009) and hence amass more cash. Similarly, the gambling (GAMB) and the restaurants and bars (RES \& BARS) subsectors' companies keep more cash. The gambling subsector need to keep more cash to tap on new technology related opportunities as according to Griffiths \& Parke (2002), the gambling in recent times has become more technology oriented, with a tremendous growth in internet gambling. Moreover, the managers in the restaurants subsector face pressure to undertake new profitable projects (Chathoth \& Olsen, 2007) and hence need to amass more cash.

Furthermore, AR (1) in Table 4 indicates the existence of negative first-order serial correlation; however, AR (2) shows the absence of second-order serial correlation. Moreover, the Hansen test results confirm the absence of any link between instruments employed and the error term, i.e., the instruments are valid.

\section{Conclusion}

In this study, unique attributes of hospitality sector i.e., high capital intensiveness, high risk, high leverage and intense competition have been considered and the results show that growth opportunities and dividend payments have a positive effect on cash holdings. Moreover, size, leverage, liquidity, cash flow, asset intangibility, cash flow volatility and stock exchange pose a negative impact on cash holdings. Furthermore, the airlines, gambling and restaurants and bars subsectors' companies keep more cash than the travel and tourism (reference subsector). The trade off, pecking order and cash flow theories are empirically supported for the hospitality sector of Western Europe.

\subsection{Theoretical Implications}

The study supports all the three theories i.e., trade off, pecking order and cash flow theories in explaining the determinants of cash holdings in the hospitality sector of Western Europe. In response to the trade off theory, larger companies in the hospitality sector are more diversified and hence amass less cash due to easy access to funds. Similarly, supporting the cash flow theory, larger hospitality sector companies hold more cash to bar the agency issues. Moreover, companies in the hospitality sector keep less cash as such companies face close monitoring and attain leverage cheaply. Supporting the trade off theory, companies in the hospitality sector hold considerable fund of cash to counter cash shortages for making investments. Furthermore, companies in the hospitality sector experiencing more cash flows keep less cash, as influx of cash flows serve as a source of liquidity. Furthermore, to be able to pay stable dividends, the hospitality sector companies amass more cash and hence support the trade off theory. 


\subsection{Managerial Implications}

Cash holdings managerial decisions are a major reason of conflict between managers and shareholders. The results help the investors of the hospitality sector to grasp the cash management decisions of managers (insiders). For instance, by utilizing the empirical findings in this study, an investor sensitive to empire-building traits of managers for their private benefits, can infer that large hospitality companies with more leverage and capital expenditures will hold less cash. These features will guide such concerned investors to opt for hospitality companies holding less cash, who depend considerably on debt or internal funds, thereby regulating mal-practices of managers dealing cash. However, holding excessive cash in such companies can create agency problems. However, large hospitality companies holding more cash would have an ease in practicing debt financing as holding more cash is an indication of diversification and expansion, making shareholders more heedful about their net earnings. In order to curtail the deleterious effect of asymmetric information between management of hospitality companies and its stakeholders (shareholders and lenders), managers not only need to understand the determinants of cash holdings but also have to devise pragmatic line of action representing corporation's real inside.

\subsection{Policy Implications}

It has been confirmed that hospitality companies of Western Europe are facing financial constraints following the negative liquidity in Table 2. Therefore, the government may come up with more new and improved policies to help the hospitality sector to overcome these constraints. Finally, this study enriches the literature on the corporate cash holdings by examining a sector with its unique characteristics and paves the way for doing further research for such companies in other countries.

\subsection{Limitations and Future Research}

The limitations of the study pose some challenges for conducting future research. The current study is focused on top five tourism destinations of Western Europe in terms of worldwide arrivals and revenue generated, which can be extended to some more countries falling in the Western Europe to get a more comprehensive insight about the cash management in the region.

\section{References}

Al-Najjar, B., \& Belghitar, Y. (2011). Corporate cash holdings and dividend payments: Evidence from simultaneous analysis. Managerial and Decision Economics, 32(4), 231-241.

Ahmad, W., \& Adaoglu, C. (2019). Cash management in the travel and leisure sector: Evidence from 
the United Kingdom. Applied Economics Letter, 26(7), 618-621.

Antonio, F., Kadyrzhanova, D., Jae W., \& Sim, J. W. (2013). Rising intangible capital, shrinking debt capacity, and the US corporate savings glut (Finance and Economics Discussion Series 2013-67). Retrieved from Federal Reserve website: https://www.federalreserve.gov/pubs/feds/2013/201367/201367pap.pdf

Arellano, M., \& Bover, O. (1995). Another look at the instrumental variable estimation of error-components models. Journal of Econometrics, 68(1), 29-51.

Bahreini, M., \& Adaoglu, C. (2018). Dividend payouts of travel and leisure companies in Western Europe: An analysis of the determinants. Tourism Economics, 24(7), 801-820.

Bates, T. W., Kahle, K. M., \& Stulz, R. M. (2009). Why do US firms hold so much more cash than they used to? The Journal of Finance, 64(5), 1985-2021.

Baum, C. F, Schaffer, M. E, \& Stillman, S. (2002). Instrumental variables and GMM: Estimation and testing (Boston College Working Papers in Economics No. 545). Retrieved from Boston College Department of Economics website: http://fmwww.bc.edu/ec-p/wp545.pdf

Bodie, Z., Kane, A., \& Marcus, A. J. (2011). Investments and portfolio management (9th ed.). New York, NY: McGraw-Hill.

Butler, K. C. (2016). Multinational finance: Evaluating the opportunities, costs, and risks of multinational operations (6th ed.). Hoboken, NJ: John Wiley \& Sons.

Chathoth, P. K., \& Olsen, M. (2007). Does corporate growth really matter in the restaurant industry? International Journal of Hospitality Management, 26(1), 66-80.

Cui, C., John, K., Pang, J., \& Wu, H. (2018). Employment protection and corporate cash holdings: Evidence from China's labor contract law. Journal of Banking $\mathcal{E}$ Finance, 92, 182-194. https://doi. org/10.1016/j.jbankfin.2018.05.011

D’Mello, R., Krishnaswami, S., \& Larkin, P. J. (2008). Determinants of corporate cash holdings: Evidence from spin-offs. Journal of Banking and Finance, 32(7), 1209-1220. https://doi.org/10.1016/j.jbankfin.2007.10.005

Dogru, T., \& Sirakaya-Turk, E. (2017). The value of cash holdings in hotel firms. International Journal of Hospitality Management, 65, 20-28. https://doi.org/10.1016/j.ijhm.2017.05.004

Drobetz, W., \& Grüninger, M. C. (2007). Corporate cash holdings: Evidence from Switzerland. Financial Markets Portfolio Management, 21, 293-324.

Ferreira, M. A., \& Vilela, A. S. (2004). Why do firms hold cash: Evidence from EMU countries? European Financial Management, 10, 295-319.

Jensen, M. C. (1986). Agency costs of free cash flow, corporate finance and takeovers. American Economic Review, 76(2), 323-339. 
Jensen, M. C., \& Meckling, W. (1976). Theory of the firm: Managerial behavior agency costs and ownership structure. Journal of Financial Economics, 3(4), 305-360.

Fichtner, J., Heemskerk, E. M., \& Garcia-Bernardo, J. (2017). Hidden power of the big three? Passive index funds, re-concentration of corporate ownership, and new financial risk. Business and Politics, 19(2), 298-326. http://dx.doi.org/10.2139/ssrn.2798653

Griffiths, M. D., \& Parke, J. (2002). The social impact of internet gambling. Social Science Computer Review, 20(3), 312-320. https://doi.org/10.1177/089443930202000308

Gu, Z., \& Kim, H. (2009). CEO cash compensation determinants: An empirical examination of US airlines. The Service Industries Journal, 29(7), 995-1005.

Han, S., \& Qiu, J. (2007). Corporate precautionary cash holdings. Journal of Corporate Finance, 13(1), 43-57. https://doi.org/10.1016/j.jcorpfin.2006.05.002

Hansen, E., \& Wagner, R. (2017). Stockpiling cash when it takes time to build: Exploring price differentials in a commodity boom. Journal of Banking E Finance, 77, 197-212.

Hardin, W. G., Highfield, M. J., Hill, M. D., \& Kelly, W. (2009). The determinants of REIT cash holdings. Journal of Real Estate Financial Economics, 39(1), 39-57.

Iacopetta, M., Minetti, R., \& Peretto, P. F. (2019). Financial markets, industry dynamics and growth. The Economic Journal, 129(621), 2192-2215.

Keynes, J. M. (2009). Characteristics of the airline industry. In A. Cento (Ed.), The airline industry: Challenges in the 21st century. (pp. 13-44). Heidelberg: Physica-Verlag. https://doi.org/10.1007/9783-7908-2088-1

Kim, H., Woods, D., \& Kim, J. (2011). Cash holding as a determinant of restaurant firm value: Seeking an optimal cash-holding level. Journal of Tourism and Leisure Research, 23(4), 483-503.

Kim, H., \& Gu, Z. (2009). Financial features of dividend-paying firms in the hospitality industry: A logistic regression analysis. International Journal of Hospitality Management, 28(3), 359-366.

Kim, J., Woods, D., \& Kim, H. (2013). Identifying the financial characteristics of cash-rich and cash-poor restaurant firms: A logistic regression analysis. Tourism Economics, 19(3), 583-598.

Lev, B. (2000). Intangibles: Management, measurement, and reporting. Washington, D. C.: Brookings Institution Press.

Lee, I., \& Shin, Y. J. (2018). Fintech: Ecosystem, business models, investment decisions, and challenges. Business Horizons, 61(1), 35-46.

Lian, Y., Sepehri, M., \& Foley, M. (2011). Corporate cash holdings and financial crisis: An empirical study of Chinese companies. Eurasian Business Reviews, 1(2), 112-124.

Maheshwari, Y., \& Rao, K. T. V. (2017). Determinants of corporate cash holdings. Global Business Review, 18(2), 416-427. 
Martínez-Sola, C., Garcia-Teruel, P. J \& Martínez-Solano, P. (2011). Corporate cash holding and firm value. Applied Economics, 45(2), 161-170.

Minton, B. A., \& Schrand, C. (1999). The impact of cash flow volatility on discretionary investment and the costs of debt and equity financing. Journal of Financial Economics, 54(3), 423-460.

Mung, S. G., \& Jang, S. (2015). Working capital, cash holding and profitability of restaurant firms. International Journal of Hospitality Management, 48, 1-11.

Mulvey, J. M., \& Holen, M. (2016). The evolution of asset classes: Lessons from university endowments. Journal of Investment Consulting, 17(2), 48-58.

Myers, S. C., \& Majluf, N. S. (1984). Corporate financing and investment decisions when firms have information that investors do not have. Journal of Financial Economics, 13(2), 187-221.

Nakamura, L. I. (2001). Investing in intangibles: Is a trillion dollars missing from the GDP? Business Review, Q4, 27-37.

Nafees, B., Ahmad, N., \& Rasheed, A. (2017). The determinants of cash holdings: Evidence from SMEs in Pakistan. Paradigms, 11(1), 111-116.

Opler, T., Pinkowitz, L., Stulz, R., \& Williamson, R. (1999). The determinants and implications of corporate cash holdings. Journal of Financial Economics, 52(1), 3-46.

Ozkan, A., \& Ozkan, N. (2004). Corporate cash holdings: An empirical investigation of UK companies. Journal of Banking and Finance, 28(9), 2103-2134.

Ozkan, N. (2007). Do corporate governance mechanisms influence CEO compensation? An empirical investigation of UK companies. Journal of Multinational Financial Management, 17(5), 349-364.

Pastor, C. C., \& Gama, P. M. (2013). Determinant factors of cash holdings: Evidence from Portuguese SMEs. International Journal of Business and Management, 8(1), 104-112.

Paskelian, O. G., Bell, S., \& Nguyen, C. V. (2010). Corporate governance and cash holdings: A comparative analysis of Chinese and Indian firms. The International Journal of Business and Finance Research, 4(4), 59-73.

Peterson, M., \& Rajan, R. (2002). Does distance still matter: The information revolution in small business lending? The Journal of Finance, 57(6), 2533-2570.

Riddick, L. A., \& Whited, T. M. (2009). The corporate propensity to save. The Journal of Finance, 64(4), 1729-1766. https://doi.org/10.1111/j.1540-6261.2009.01478.x

Shleifer, A., \& Vishny, R. W. (1992). Liquidation values and debt capacity: A market equilibrium approach. The Journal of Finance, 47(4), 1343-1366.

Singal, M. (2015). How is the hospitality and tourism industry different? An empirical test of some structural characteristics. International Journal of Hospitality Management, 47, 116-119. 
Sultanov, B. (2018). Testing the pecking order theory of capital structure: Kazakhstan experience (Master's thesis, Nazarbayev University, Astana, Kazakhstan). Retrieved from https://nur.nu.edu.kz/handle/123456789/3192

Tahir, M. S., Alifiah, M. N., Arshad, M. U., \& Saleem, F. (2016). Financial theories with a focus on corporate cash holding behavior: A comprehensive review. International Journal of Economics and Financial Issues, 6(3S), 215-219.

Williamson, O. (1988). Corporate finance and corporate governance. The Journal of Finance, 43(3), $567-591$.

Wooldridge, F. M, (2001). Applications of generalized method of moments estimation. Journal of Economic Perspectives, 15(4), 87-100.

World Tourism Organization. (2018). UNWTO Tourism Highlights (2018 ed.). Madrid, Spain. https:// doi.org/10.18111/9789284419876

Uyar, A., \& Kuzey, C. (2014). Determinants of corporate cash holdings: Evidence from emerging market of Turkey. Applied Economics, 46(9), 1035-1048.

Yung, K., \& Chen, C. (2018). Managerial ability and firm risk-taking behavior. Review of Quantitative Finance and Accounting, 51(4), 1005-1032. 
